\title{
Celecoxib was similar to naproxen for rheumatoid arthritis with fewer endoscopic ulcers
}

Simon LS, Weaver AL, Graham DY, et al. Anti-inflammatory and upper gastrointestinal effects of celecoxib in rheumatoid arthritis. A randomized controlled trial.JAMA 1999 Nov 24;282:1921-8.

QUESTION: In patients with rheumatoid arthritis (RA), is celecoxib as efficacious (in anti-inflammatory and analgesic effects) and safe (in avoiding endoscopic upper gastrointestinal [Gl] ulcers) as naproxen?

\section{Design}

Randomised (allocation concealed*), blinded (patients, clinicians, and outcome assessors), ${ }^{*}$ placebo controlled, 12 week trial.

\section{Setting}

79 US and Canadian clinical sites.

\section{Patients}

1149 patients (mean age 54 y, 73\% women) who had RA (American College of Rheumatology criteria) for $>3$ months. Inclusion criteria were age $\geqslant 18$ years and receipt of stable medications; oral steroids and disease modifying antirheumatic drugs were allowed. Exclusion criteria were active GI tract, renal, hepatic, or coagulation disorders; history of cancer or gastric or duodenal surgery; or recent or current oesophageal or gastroduodenal ulcers or $\geqslant 10$ erosions. $60 \%$ of patients completed the study; follow up was $>99 \%$.

\section{Intervention}

Symptomatic RA was confirmed after non-steroidal anti-inflammatory drugs (NSAIDs) and analgesics were stopped for 2 to 7 days. Patients were then allocated to celecoxib, $100 \mathrm{mg}$ twice/d $(\mathrm{n}=240), 200 \mathrm{mg}$ twice/day $(\mathrm{n}=235)$, or $400 \mathrm{mg}$ twice/day $(\mathrm{n}=218)$; naproxen, $500 \mathrm{mg}$ twice/day $(\mathrm{n}=225)$; or placebo $(\mathrm{n}=231)$. NSAIDs, injectable corticosteroids, anticoagulants, and antiulcer drugs were prohibited.

\section{Main outcome measures}

Improvement in signs and symptoms of RA (8 measures), proportion of patients with endoscopic GI ulcers at 12 weeks, and adverse effects.

\section{Main results}

Patients in the celecoxib and naproxen groups had similar outcomes, with more improvements at 12 weeks in signs and symptoms of RA than with placebo ( 5 of 8 measures for the celecoxib, $100 \mathrm{mg}$ group; 7 of 8 measures for the celecoxib, $200 \mathrm{mg}$ and $400 \mathrm{mg}$ groups; and 4 of 8 measures for the naproxen group). Similar patterns were shown at 2 and 6 weeks. Patients in the placebo group withdrew from the study more often because of treatment failure than did patients in the celecoxib or naproxen groups $(\mathrm{p}<0.001$ for all comparisons). The placebo and celecoxib groups did not differ for endoscopic GI ulcers; more patients in the naproxen group had ulcers than did those in the other 4 groups $(p<0.001)$, although endoscopy was done in only $57 \%$ of patients. The rate of total adverse effects was $19 \%$ for placebo; $28 \%, 25 \%$, and $26 \%$ for the $100 \mathrm{mg}$, $200 \mathrm{mg}$, and $400 \mathrm{mg}$ celecoxib groups, respectively; and $31 \%$ for naproxen.

\section{Conclusions}

Celecoxib was as effective as naproxen for improving signs and symptoms of rheumatoid arthritis with similar rates of adverse effects and withdrawals. Celecoxib was associated with fewer endoscopic gastrointestinal ulcers.

*See glossary.
Source of funding: GD Searle E $\mathrm{Co}$

For correspondence: Dr LS Simon, Beth Israel Deaconess Medical Center, 110 Francis Street, Suite 5 C, Boston, $M A$ 02215, USA. Fax +1 6176327795.

Table 2 Summary of data from randomised trials of gastrointestinal (GI) events with cyclofloxgenase-2 inhibitors $v$ conventional non-steroidal anti-inflammatory drugs (NSAIDs) for patients with rheumatoid arthritis or osteoarthritis*

\begin{tabular}{|c|c|c|c|c|c|}
\hline Outcomes at 6 to 52 wk & Study & Comparison & Event rates & $\operatorname{RRR}(95 \% \mathrm{Cl})$ & NNT (CI) \\
\hline \multirow[t]{3}{*}{ Endoscopic ulcers $\geqslant 3 \mathrm{~mm}$} & Simon† & Celecoxib $v$ naproxen & $5 \% \vee 26 \%$ & $79 \%(66$ to 87$)$ & 5 (4 to 8$)$ \\
\hline & Emerył & Celecoxib $v$ diclofenac & $4 \% \vee 16 \%$ & $73 \%(44$ to 87$)$ & $9(6$ to 19$)$ \\
\hline & Laine§ & Rofecoxib $v$ ibuprofen & $5 \% \vee 25 \%$ & $79 \%(66$ to 87$)$ & $6(4$ to 8$)$ \\
\hline \multirow[t]{3}{*}{ Dyspepsia } & Simont & Celecoxib $v$ naproxen & $4 \% \vee 5 \%$ & $21 \%(-5$ to 59$)$ & Not significant \\
\hline & Emerył & Celecoxib $v$ diclofenac & $10 \% \vee 13 \%$ & $23 \%(-18$ to 50$)$ & Not significant \\
\hline & Langman \| & Rofecoxib $v 3$ NSAIDs & $23.5 \%$ v $25.5 \%$ & Data not available & Data not available \\
\hline \multirow{4}{*}{$\begin{array}{l}\text { Gl events leading to discontinuation of } \\
\text { treatment }\end{array}$} & Simont & Celecoxib $v$ naproxen & $1 \% \vee 2 \%$ & $54 \%(-35$ to 85$)$ & Not significant \\
\hline & Emerył & Celecoxib $v$ diclofenac & $6 \% \vee 16 \%$ & $64 \%(41$ to 79$)$ & 11 (7 to 19$)$ \\
\hline & Laine§ & Rofecoxib $v$ ibuprofen & $8 \% \vee 29 \%$ & $73 \%(60$ to 82$)$ & 5 (4 to 7 ) \\
\hline & Langman \| & Rofecoxib $v 3$ NSAIDs & $5.7 \% \vee 7.8 \%$ & Data not available & Data not available \\
\hline \multirow[t]{4}{*}{ Major Gl event or major bleeding } & Simont & Celecoxib $v$ naproxen & $0 \% \vee 0.4 \%$ & $100 \%(-25$ to 100$)$ & Not significant \\
\hline & Emerył & Celecoxib $v$ diclofenac & $0 \% \vee 1 \%$ & $100 \%$ (37 to 100$)$ & 82 (33 to 2360$)$ \\
\hline & Laine§ & Rofecoxib $v$ ibuprofen & $0.2 \% \vee 1 \%$ & $76 \%(-84$ to 97$)$ & Not significant \\
\hline & Langman \| & Rofecoxib v 3 NSAIDs & $1.3 \% \vee 1.8 \%$ & Data not available & Data not available \\
\hline \multicolumn{6}{|c|}{$\begin{array}{l}\text { *RRR, NNT, and Cl calculated from data in article or provided by author (Laine). } \\
\text { †Simon = Simon LA, Weaver AS, Graham DY, et al. JAMA 1999;282:1921-8. (3 doses of celecoxib combined, } 12 \text { wk trial). } \\
\text { fEmery = Emery P, Zeidler H, Kvien TK, et al. Lancet 1999;354:2106-11. (24 wk trial). } \\
\text { §Laine = Laine L, Harper S, Simon T, et al. Gastroenterology 1999;117:776-83. (24 wk trial with main analysis based on } 12 \text { wk data provided by author). } \\
\text { \| Langman = Langman MJ, Jensen DM, Watson DJ, et al. JAMA 1999;282:1929-33. (systematic review of } 8 \text { studies of } 6 \text { wk to } 1 \text { y of duration, drug company-funded review. NSAIDs were ibu- } \\
\text { profen, diclofenac, and nabumetone). }\end{array}$} \\
\hline
\end{tabular}

